\title{
PERKEMBANGAN PENANAMAN GETAH DI SABAH, 1892-1941
}

\author{
Jinel Noin
}

\begin{abstract}
This article focuses on the rubber cultivation activities in Sabah before World War II and draws from several sources such as government files and reports, newspapers and books. Generally, the entry of the North Borneo Chartered Company (NBCC) administration in 1881 changed Sabah's economic pattern. Previously the main activities of the local population concentrated economic on self-sufficiency had little interaction with outside world. However, a transformation began to occur when NBCC introduced plantation crops like tobacco, sago, coconut, coffee and rubber. In this article, rubber plantation is given attention because it provided substantial revenue to the country. In the Rubber cultivation activities in Sabah reached an impressive level where it became a major export for the NBCC government. The rubber development in this period showed that it was an important part of the Sabah economic structure. These activities expanded rapidly with the construction of railways where nearby areas were opened for agriculture. In addition, the entry of Chinese and Javanese labour and capital inflows from foreign investors and government policies also saw the rapid growth of the industry.
\end{abstract}

\section{Pengenalan}

Sebelum pentadbiran Sabah diambil alih oleh Syarikat Berpiagam Borneo Utara (SBBU) pada tahun 1881, ekonomi masyarakatnya tertumpu kepada kegiatan sara diri, berskala kecil dan tiada tanaman komersil diusahakan. Walaupun hubungan perdagangan dengan pedagang Cina dan orang Melayu terjalin, namun hanya segelintir kolompok sahaja yang terlibat. Sistem perhubungan dan 
perkembangan teknologi yang terhad turut menghalang perluasan kegiatan ekonomi. Walau bagaimanapun, keadaan ini mula berubah apabila SBBU memulakan pentadbiran apabila mereka mengeksploitasi hasil bumi supaya kewangan dapat dikukuhkan. Hasil hutan dan hasil laut dimajukan kemudian dieksport ke Singapura, China, Hong Kong dan Eropah. Salah satu barang eksport paling menguntungkan ialah sarang burung yang diperoleh dari Gua Gomantong, Gua Madai, Baturang, Taparong, Melakop dan Penunggah. Manakala rotan mentah dieksport untuk menghasilkan pemidang, tikar, tangkai payung, tongkat dan alat perabot. Pembalakan pula dijalankan di beberapa kawasan seperti Sandakan, Lahad Datu dan Tawau. Eksport pertama balak ke Australia dilakukan pada tahun 1885 dan eksport diperluaskan ke China, Singapura, Jepun dan England. Pada tahun 1910, balak merupakan hasil eksport kedua terbesar selepas tembakau. Pada ketika ini, tembakau merupakan tanaman dagangan yang penting dan diutamakan. Ladang yang pertama dibuka di Sandakan sekitar tahun 1843 dan menjelang tahun 1890, kira-kira 61 buah ladang beroperasi di sekitar Lahad Datu, Sandakan dan Tawau. Komoditi ini menjadi bahan eksport penting berikutan permintaan dan harga tinggi di pasaran dunia. Walau bagaimanapun, tanaman getah menjadi lebih popular selepas diperkenalkan di rantau Asia Tenggara.

\section{Penglibatan SBBU dalam Pertanian Ladang}

Selepas memantapkan kedudukan dalam pentadbiran negeri Sabah, SBBU mengambil langkah untuk memantapkan ekonomi mereka dengan melibatkan diri dalam pertanian perladangan. Langkah ini dilakukan kerana diyakini kegiatan tersebut akan mampu memberi pulangan yang lumayan kepada syarikat dalam jangka masa panjang. Sebaik sahaja mendapat piagam untuk mentadbir, SBBU berusaha menarik minat pemodal-pemodal asing untuk melabur dalam kegiatan ekonomi mereka. Sementara itu, pelabur-pelabur modal Eropah pula meletakkan harapan yang begitu tinggi agar SBBU boleh menjalankan satu bentuk pentadbiran yang mantap bagi menjamin keselamatan pelaburan mereka di Sabah. Ini menunjukkan bahawa para pelabur Eropah dan SBBU mempunyai matlamat tersendiri iaitu untuk mengaut keuntungan dalam bidang ekonomi.

Pada awalnya, hasil-hasil pertanian yang diusahakan oleh SBBU lebih tertumpu kepada tanaman yang tidak melibatkan modal tinggi. SBBU cuba menanam tanaman seperti tebu, ubi kayu, ganja, sutera, kacang soya, orkid dan nanas namun percubaan ini mengalami kegagalan. Oleh itu, penanaman kopi dan lada hitam telah diusahakan 
tetapi harga kedua-dua komoditi di pasaran menyebabkan penanamannya tidak menggalakkan. Penanaman kelapa turut diusahakan kerana penting untuk menghasilkan minyak dan juga untuk tujuan eksport. Selain itu, terdapat juga sejenis tanaman yang penting ditanam iaitu manila hemp. Kebun kelapa di Tawau ditanam oleh Kuhara Company dengan manila hemp dan mula mengeksport hasilnya pada tahun 1919. Apabila harga getah jatuh pada tahun 1930, eksport komoditi ini semakin meningkat. Kesan daripada kejatuhan harga getah juga, SBBU telah bertindak untuk mengusahakan tanaman lain seperti tanaman padi. Hal ini kerana, padi merupakan makanan asas kepada penduduk tempatan di Sabah. SBBU menggalakkan penanaman padi supaya menjadi lebih luas apabila Jabatan Pertanian memberi perhatian kepada aktiviti pertanian orang tempatan. Penyakit belalang juta yang menyerang tanaman ini juga dihapuskan dan negeri Sabah berjaya menghasilkan 257,268 pikul padi pada tahun 1939. Manakala, penanaman sagu di Semenanjung Klias diusahakan untuk menggantikan peranan padi sebagai makanan penduduk. Tanaman tersebut diusahakan secara besar-besaran dan hasilnya dieksport ke Labuan kemudian ke Singapura. ${ }^{1}$

Tanaman-tanaman ini diberikan perhatian berdasarkan potensinya untuk diusahakan secara komersil adalah cerah berbanding dengan tanaman lain. Sebagai contohnya, tanaman sagu dan kelapa yang telahpun diusahakan oleh penduduk tempatan dan penduduk Cina sebelum ini telah diperluaskan kepada skala yang lebih besar. ${ }^{2}$ SBBU mengusahakan tanaman ini dalam bentuk yang lebih besar kerana mempunyai nilai ekonomi yang sangat tinggi dan berpotensi untuk dimajukan. ${ }^{3}$ Oleh sebab itulah, tanaman yang dilihat boleh memberikan keuntungan lumayan akan menjadi tumpuan SBBU. Walau bagaimanapun, tanaman utama yang diusahakan secara besarbesaran lebih tertumpu kepada penanaman tembakau dan getah. Tembakau mendominasi eksport Sabah sejak pentadbiran SBBU apabila tanaman tersebut diusahakan secara besar-besaran dan berjaya menembusi pasaran di London, Amsterdam dan Amerika Syarikat. Jumlah eksport tembakau paling tinggi dicapai pada tahun 1902 apabila berjaya memperoleh pendapatan sebanyak $\$ 2,018,182$. Namun demikian, hasil eksport menurun kemudiannya dan getah muncul kembali sebagai tanaman ladang paling penting sehinggalah Perang Dunia Kedua meletus.

Faktor utama yang menyebabkan SBBU melibatkan diri dalam pertanian ladang adalah disebabkan oleh sektor ini mampu memberikan keuntungan yang tinggi berbanding aktiviti-aktiviti ekonomi yang lain. Misalnya, tembakau memerlukan masa kurang 
daripada setahun untuk memperlihatkan hasil. Tambahan pula, revolusi industri yang sedang berkembang pesat di negara-negara Eropah memerlukan hasil pertanian dan bahan mentah khususnya dari negara-negara Asia. Berdasarkan permintaan yang tinggi terhadap keluaran pertanian, SBBU melihat masa depan aktiviti tersebut sangat cerah dan berusaha melibatkan diri secara maksimum dalam aktiviti ini. ${ }^{4}$ Selain itu, kekurangan modal SBBU untuk memajukan aktiviti pembalakan dan sumber galian pada awal pentadbiran juga merupakan satu dorongan kuat untuk mereka melibatkan diri dalam aktiviti pertanian. Oleh itu, SBBU memperuntukkan modal dengan menumpukan perhatian kepada aktiviti pertanian yang tidak memerlukan kos dan modal yang tinggi tetapi mampu memberikan keuntungan cepat.

\section{Perkembangan Awal Penanaman Getah di Sabah, 1892-1905}

Kemasukan benih getah ke Sabah tidak dapat dipastikan dengan jelas kerana ketiadaan dokumen rasmi yang menyatakan secara terperinci bila dan bagaimana benih tersebut dibawa masuk. Namun demikian terdapat laporan yang menyatakan bahawa adanya getah jenis Ceara Rubber dan India Rubber di kebun eksperimen Silam. Menurut Kuat Kwai Fong, William Preyer pernah mencadangkan penanaman India Rubber pada tahun 1885 dan sehingga tahun 1888. Dalam tempoh tersebut, kira-kira 10,000 pokok telah ditanam oleh British Borneo Trading \& Planting Company, Taurid, S.B.J. Skertchly, Preyer dan Brahim. Namun demikian, dalam usaha memperluaskan tanaman itu, mereka menghadapi masalah untuk mendapatkan biji benih dan tapak semaian. ${ }^{5}$ Walau bagaimanapun, eksport India Rubber agak memberangsangkan dengan mencatat jumlah eksport sebanyak $\$ 49,513$ pada tahun 1897 dan meningkat sebanyak $\$ 79,600$ pada tahun $1898 .{ }^{6}$

Penanaman getah jenis Hevea Brasiliensis bermula pada tahun 1882 apabila pokok getah dari Botanical Garden Singapura dihantar ke Sabah. Terdapat juga rekod yang menyatakan bahawa benih getah telah dibawa dari Ceylon pada tahun 1887. Walau bagaimanapun, tidak dapat dipastikan dengan jelas punca yang berlaku terhadap kiriman awal pokok getah ini. ${ }^{7}$ Kemasukan tanaman ini tidak diambil perhatian oleh pegawai-pegawai SBBU kerana mereka tidak yakin tanaman tersebut mampu dibangunkan secara komersil. Pada tahun 1884, kebun eksperimen kerajaan di Silam cuba menanam getah di sepanjang jalan untuk meredupkan jalan masuk ke kebun tersebut. Dalam mesyuarat pemegang-pemegang saham SBBU pada Disember 1895, Wagstaff mengemukakan persoalan mengenai kesesuaian 
penanaman getah di Sabah dan pengerusi pemegang saham SBBU, R.B. Martin menyuarakan sokongan terhadap pandangan itu. ${ }^{8}$

Eksperimen menanam Para Rubber dilakukan buat pertama kalinya pada tahun 1892 apabila beberapa pelopor menyatakan bahawa tanaman ini akan berjaya sekiranya ditanam dalam skala perusahaan. ${ }^{9}$ Dalam tahun tersebut, R.M. Wade bersama saudaranya menjadi perintis kepada penanaman getah komersil untuk Mortgage Investments and Contract Corporation Limited di Bongaya dekat Sungai Labuk. ${ }^{10}$ Pada tahun 1899, mereka memulakan pembersihan kawasan sebanyak 200 ekar tetapi hanya 75 ekar sahaja yang ditanam dengan getah. Pada tahun 1901, estet tersebut telah diiklankan untuk dijual kerana usaha yang lakukan oleh mereka itu dilihat tidak menggalakkan. ${ }^{11}$ Sementara itu, British North Borneo Trading Company menanam sebanyak 40,000 anak pokok getah di Sekong dan menjelang bulan Jun 1905, mereka mula menoreh sebahagian daripada hasilnya. Di Pitas pula satu setengah ekar telah ditanam dengan getah pada tahun $1898 .{ }^{12}$

Seterusnya benih getah yang diperoleh dari Ceylon mula ditanam di Tenom dan Pantai Barat. Pegawai Daerah Tenom, C.H. Keasberry bertanggungjawab terhadap aktiviti di kebun eksperimen Tenom. Pada tahun 1900, beliau telah menerima sebungkus biji benih tetapi tidak dinyatakan ciri-cirinya dan dengan anggapan bahawa bijih benih tersebut ialah benih sejenis buah. Lalu, beliau menanam bijih benih tersebut di tapak semaian sebelum dipindahkan ke kebun. Namun, beliau masih tidak dapat mengenal pasti tanaman tersebut ialah pokok getah sehinggalah zaman "zoom" getah. ${ }^{13}$ Walau bagaimanapun, percubaan itu agak mengecewakan kerana kumpulan pokok yang ditanam itu tidak dijaga dengan rapi dan dibiarkan sehingga satu per empat daripadanya mempunyai lebih dua atau tiga cabang. Meskipun begitu, baki pokok yang masih ada mula ditoreh oleh F.E. Lease pada tahun 1905 di bawah satu perjanjian dengan kerajaan. ${ }^{14}$ Perkembangan industri getah di Sabah hampir sama dengan perkembangan di Indonesia akibat daripada kejatuhan harga tembakau pada tahun 1891. Hal ini secara langsung telah menyebabkan ramai pengusaha beralih kepada penanaman getah. Krisis tembakau pada ketika itu telah menyaksikan penurunan harga yang begitu dramatik dan kebanyakan daripada syarikat pengusaha bankrap. ${ }^{15}$

Pada tahun 1905, penanaman getah terbukti mampu memberikan hasil yang menguntungkan dan mula menjadi perusahaan komersil. Kepesatan perkembangan industri ini berjaya membuka peluang pelaburan untuk membangunkan sumber-sumber lain. ${ }^{16}$ Namun begitu, tidak ramai pelabur dan pengusaha ladang mengambil bahagian dalam aktiviti ini kerana Sabah terletak jauh dari jalan laluan utama di Laut China Selatan. Kedudukan geografinya dikatakan terpencil dan kurang 
populasi serta mengalami masalah kekurangan bekalan tenaga buruh. Halangan terbesar yang dihadapi adalah kesukaran untuk meyakinkan pelabur kerana pokok getah memerlukan tempoh enam tahun untuk mencapai tahap matang sebelum mengeluarkan hasil. Oleh itu, kebanyakan pelabur berfikir sebanyak dua kali kerana jumlah modal pelaburan yang diperlukan agak tinggi sedangkan para pemegang saham tidak sabar untuk menanti pulangan yang cerah.

Peluang industri ini dilihat semakin cerah untuk diperkembangkan apabila kerajaan mula campur tangan dalam menggalakkan kemasukan modal pelaburan. Langkah ini dilakukan kerana industri pembuatan motokar di Amerika Syarikat pada ketika itu semakin pesat berkembang. ${ }^{17}$ Kerajaan berpendapat bahawa penanaman getah seharusnya diusahakan secara besar-besaran dan dijadikan sebagai satu perusahaan yang paling menguntungkan. Selain itu, SBBU juga mahu menjadikan Sabah sebagai pengeluar getah utama di Asia Tenggara. ${ }^{18}$ Dalam jamuan makan malam tahunan SBBU dan para pemegang saham pada 12 Disember 1905, W.C. Cowie (Pengarah Urusan SBBU) telah mengumumkan dua intensif untuk mengatasi kesukaran mendapatkan modal daripada pelabur sekaligus membantu perkembangan industri tersebut. ${ }^{19}$

Intensif pertama ialah kerajaan memberikan satu jaminan bahawa cukai eksport tidak akan dikenakan kepada syarikat penanam getah selama 50 tahun bermula 1905. Intensif kedua pula adalah pemberian jaminan dividen kepada mana-mana syarikat perusahaan getah yang beroperasi pada masa non-produktif. Di bawah skim ini, kerajaan menjual tanah kepada syarikat-syarikat pengusaha getah dengan harga $£ 12.70$ sen seekar dan hasil jualan tanah itu digunakan sebagai modal persediaan semasa non-produktif. Dasar ini menyaksikan 12 buah syarikat dibentuk berasaskan terma tersebut. Kejayaan pertama dicapai adalah pada tahun 1905 dan kejayaan tersebut berlaku secara berterusan sehingga industri mencapai zaman "boom" pada tahun 1910.

Jaminan pembayaran dividen ini adalah bertujuan untuk memperluaskan aktiviti ini tanpa wujud sebarang sempadan. ${ }^{20}$ Walau bagaimanapun, usaha untuk memperkembangkan perusahaan itu bukanlah dilakukan oleh kerajaan sahaja tetapi turut dibantu oleh syarikat perusahaan yang telahpun sedia ada pada ketika itu. Misalnya, North Borneo Trading Company yang mempunyai kawasan tanah yang luas berusaha untuk mewujudkan anak syarikatnya khas untuk menjalankan perusahaan getah. Selain itu, syarikat-syarikat yang mengusahakan tembakau pula mula menumpukan perhatian kepada getah dan memperuntukkan sebahagian tanah mereka untuk menanam tanaman tersebut. ${ }^{21}$ 


\section{Zaman Perlambungan Industri Getah, 1905-1914}

Selepas kerajaan melaksanakan dasar tanpa cukai dan jaminan dividen, syarikat-syarikat pengusaha Eropah mula menunjukkan reaksi yang menggalakkan. Banyak syarikat ditubuhkan dan melibatkan diri secara langsung dalam industri-industri tersebut. British Borneo Para Rubber Company merupakan syarikat pertama yang mengeksploitasi tawaran kerajaan itu dengan memperoleh kawasan seluas 809 ekar berdekatan dengan landasan keretapi Weston-Beaufort pada tahun 1905. Pada tahun 1906, Tenom Rubber Company Limited memilih kawasan seluas 4,405 ekar di Beaufort dan Menggatal untuk menanam getah. Sementara itu, Manchester North Borneo Rubber Limited mendapatkan kawasan seluas 5,260 ekar di Melalap dan Langkon North Borneo Rubber Limited yang beroperasi di sekitar Teluk Marudu dan memegang konsesi sebanyak 4,855 ekar. ${ }^{22}$

Jadual 1: Senarai Syarikat getah yang beroperasi di Sabah pada tahun 1907.

\begin{tabular}{|lll|}
\hline Syarikat & $\begin{array}{l}\text { Keluasan } \\
\text { tanaman } \\
\text { (ekar) }\end{array}$ & $\begin{array}{l}\text { Modal } \\
\text { (£ pound } \\
\text { sterling) }\end{array}$ \\
\hline British North Borneo Para Rubber & 3,000 & 20,000 \\
British North Borneo Company & 20,000 & 200,000 \\
Langkon Borneo Rubber Company Limited & 12,000 & 100,000 \\
Manchester North Borneo Company Limited & 13,000 & 100,000 \\
Sapong \& Tobacco Estates Limited & 30,960 & 100,000 \\
The Tenom Borneo Para Rubber Company Limited & 10,000 & 100,000 \\
\hline
\end{tabular}

Sumber: Diubahsuai daripada S/F 1423, "Planting in British North Borneo", Printed at Government Printing Office British North Borneo, Sandakan 1907, hlm. 10.

Pada tahun 1907, kebanyakan syarikat mula menggunakan modal besar untuk mengusahakan getah pada keluasan yang semakin meningkat. Berdasarkan jadual, British North Borneo Para Rubber telah menggunakan modal sebanyak $£ 20,000$ untuk menjalankan perusahaan di kawasan seluas 3,000 ekar tanah. Modal terbesar sekali dicatatkan pada masa itu ialah sebanyak $£ 200,000$ dan modal tersebut digunakan oleh British North Borneo Company untuk membiayai penanaman seluas 20,000 ekar. Manakala, empat syarikat perusahaan yang lain iaitu Langkon Borneo Rubber Company Limited, Manchester North Borneo Company Limited, Sapong \& Tobacco Estates Limited dan Tenom Borneo Para Rubber Company Limited masing-masing memperuntukkan modal sebanyak $£ 100,000$ untuk menjalankan perusahaan di kawasan masing-masing iaitu 12,000 ekar, 13,000 ekar, 30,960 ekar dan 10,000 ekar. ${ }^{23}$ 
Dalam pada itu, Beaufort Rubber Company Limited telah dibentuk dan memegang konsesi sebanyak 3,237 ekar berhampiran dengan landasan keretapi Beaufort-Weston. Pada tahun 1908, memperlihatkan penubuhan satu lagi syarikat baru iaitu North Borneo State Rubber Company dan syarikat tersebut berjaya memiliki sebanyak 2,033 ekar tanah. ${ }^{24}$ Sekong Rubber Company Limited juga telah ditubuhkan dan mengusahakan kawasan seluas 8,711 ekar. Keyakinan bahawa penanaman getah semakin meningkat pada tahun 1909, ditunjukkan dengan pembukaan empat ladang baru di Bongawan, Kimanis, Lok Kawi dan Membakut. Secara puratanya, setiap ladang baru itu mempunyai keluasan sebanyak 2,033 ekar. Meskipun harga getah lazimnya tinggi, namun hanya dua syarikat baru telah didaftarkan pada tahun $1910 .{ }^{25}$

Selepas satu dekad getah ditanam secara komersil, para pengusaha getah dan pelabur yang menyumbangkan modal dalam perusahaan tersebut mampu menikmati keuntungan dengan kadar yang tinggi dan lumayan. Keadaan ini membolehkan kerajaan menguasai aktiviti ekonomi perladangan dengan menjadikan getah sebagai komoditi eksport terbesar. Pada tahun 1910, kerajaan menanam getah seluas 5,114 ekar (tidak termasuk 33,177 ekar yang dipegang) sekaligus mencapai tahap perkembangan pesat kerana jumlah keluasan tanaman getah di Sabah pada ketika itu hampir menyamai jumlah di Selangor iaitu 37,490 ekar. Pada tahun 1911, jumlah hasil negeri mencapai $£ 200,000$ dan ianya banyak disumbangkan oleh eksport getah yang mencapai zaman boom pada tahun 1909 dan $1910 .^{26}$

Faktor kepesatan tanaman getah pada peringkat ini bukanlah hanya disebabkan oleh dasar dan galakan kerajaan tetapi juga dipengaruhi oleh sistem pengangkutan yang efektif terutamanya kemudahan keretapi. Pembinaan landasan keretapi ${ }^{27}$ merupakan pengaruh yang sangat dominan untuk membolehkan industri tersebut diperluaskan terutamanya di Pantai Barat dan Pedalaman. Pada mulanya, kebanyakan tanah di kawasan tersebut tidak dibangunkan tetapi Jabatan Pertanian mencadangkan tanaman baru diusahakan. Perkembangan pesat estet-estet di Tanah Melayu dan perkembangan industri membuat kereta di Amerika juga mempengaruhi aktiviti menanam getah di sepanjang kawasan berdekatan landasan keretapi semakin pesat. ${ }^{28}$

Selain itu, bekalan buruh juga mempengaruhi kepesatan industri kerana buruh berupaya memenuhi keperluan setiap estet terutamanya kerja-kerja pembersihan, menanam anak pokok getah, menjaga, menoreh serta mengumpul hasil susu getah. Kepentingan peranan mereka lebih jelas lagi apabila semakin banyak estet yang dibuka. Keperluan ini menyebabkan usaha-usaha untuk merekrut buruh dari 
luar giat dijalankan oleh kerajaan dan syarikat-syarikat perusahaan. Semenjak tanaman estet diperkenalkan, keperluan tenaga buruh menjadi semakin penting. Walau bagaimanapun, hanya pengusaha-pengusaha estet tembakau yang memberi perhatian serius terhadap perkara ini dan aktiviti merekrut buruh dari China mula dijalankan. Oleh kerana setiap pengusaha ingin mempercepatkan pembukaan estet baru, banyak pengusaha bimbang tentang kesukaran mendapatkan bekalan buruh kerana berlaku persaingan untuk mendapatkan buruh tempatan. ${ }^{29}$

Menjelang awal abad ke-20, tanaman getah semakin mendapat tempat dalam kalangan pengusaha Eropah. Namun begitu, tidak banyak tenaga buruh yang mampu dibekalkan dan buruh dari China dan Pulau Jawa terpaksa diimport. Keperluan tenaga buruh semakin meningkat dan pada tahun 1910, kerajaan telah menghantar Young Riddel ke negara China untuk berunding mengenai pengrekrutan buruh. Hasilnya, sebuah agensi merekrut buruh di China berjaya diwujudkan bagi memudahkan urusan membawa buruh ke Sabah. ${ }^{30}$ Mereka dibawa melalui sistem kontrak kerja selama 300 hari dengan diberikan perkhidmatan perubatan, perumahan dan pelayaran secara percuma. Selepas kontrak tamat, buruh tersebut akan diberikan tanah tidak melebihi dua ekar.

Pada tahun 1911, jumlah buruh kontrak di Sabah adalah sebanyak 20,871 orang dan sebanyak 3,736 daripada jumlah tersebut terdiri daripada buruh Cina, 4,097 buruh Jawa dan 3,338 buruh tempatan. ${ }^{31}$ Pada pertengahan tahun 1910, setiap estet telah lengkap dengan bekalan buruh namun populasi buruh yang tidak bekerja juga semakin bertambah. Pada masa ini, pemecatan buruh yang diimport mula berlaku akibat kemelesetan industri. Oleh itu, kerajaan menetapkan syarat bahawa setiap buruh mesti menandatangani satu perjanjian bertulis untuk bekerja. Bagi mewujudkan hubungan yang baik antara pekerja dan majikan, buruh yang disambung kontrak hanya dikehendaki memberi keterangan lisan sahaja dan tidak perlu membuat perjanjian bertulis. ${ }^{32}$

\section{Perkembangan Getah Selepas Perang, 1915-1920}

Selepas Perang Dunia Pertama ${ }^{33}$ tamat, keadaan harga getah di pasaran semakin menggalakkan berikutan permintaan kembali meningkat. Peningkatan ini menyebabkan kebanyakan pengusaha di Asia Tenggara meningkatkan usaha untuk memajukan perusahaan mereka demi mendapatkan keuntungan berganda selepas mengalami kerugian akibat perang. Semasa perang, kebanyakan pengeluar terpaksa membekukan hasil keluaran di pelabuhan-pelabuhan kerana tiada pengangkutan untuk membawa hasil tersebut ke negara Eropah. 
Usaha keras telah dilakukan oleh kebanyakan pengusaha getah di Sabah sekitar tahun 1915 hingga 1920.

Antara faktor yang menyebabkan perusahaan getah semakin meningkat selepas perang adalah disebabkan oleh kejatuhan harga tembakau secara mendadak. Pada tahun 1914, perusahaan getah agak memberangsangkan apabila kuantiti eksportnya meningkat kepada 34 peratus. Walau bagaimanapun, hutang yang banyak menyebabkan harganya jatuh sehingga hasilnya dikurangkan sebanyak $£ 18,000$. Meskipun, keluaran getah Sabah dikatakan antara yang berkualiti tinggi dan mempunyai harga tinggi di pasaran, namun masa depan industri ini sukar diramal. Ini terbukti pada tahun 1914 apabila perang menjejaskan ekonomi dunia dan memberi implikasi yang parah kepada industri getah di Asia Tenggara. ${ }^{34}$ Namun begitu, eksportnya meningkat kembali pada tahun 1915 setelah hasil keuntungan mencapai sehingga $2,353,412$ paun dengan nilai $£ 274,000$ berbanding $£ 190,000$ tahun sebelumnya. ${ }^{35}$

\section{Kawasan Penanaman Getah}

Seperti di Tanah Melayu, jumlah kawasan tanaman getah pada awal tahun 1910-an amat menggalakkan dan syarikat-syarikat yang beroperasi menggandakan pengeluaran mereka selepas perang. Walaupun demikian, keadaan telah berubah pada lewat tahun 1910an apabila pekebun kecil (Cina dan orang tempatan) mula melibatkan diri secara langsung dalam industri dengan memiliki kebun sendiri. Pada tahun 1914, purata kawasan yang ditanam oleh syarikat-syarikat perusahaan adalah sebanyak 10,680 ekar dan jumlah ini memberikan nilai yang tinggi iaitu 85 peratus. Namun demikian, nilai tersebut jatuh kepada 52 peratus pada tahun 1921 dan purata tanaman setiap syarikat mencapai sehingga 12,289 ekar. Sebahagian besar kawasan tanaman disumbangkan oleh syarikat yang menerima dividen. ${ }^{36}$ Statistik keluasan tanaman getah pada tahun 1915 lebih besar berbanding tahun 1914 iaitu meningkat sebanyak 511 ekar. Kawasan tanaman pada ketika ini adalah sebanyak 29,827 ekar dan 21,339 daripadanya di Pantai Barat, 3,165 di Pedalaman, 2,794 di Sandakan, 1,754 di Kudat dan 955 ekar di Pantai Timur. ${ }^{37}$ Dalam tempoh tiga tahun, jumlah tersebut menunjukkan peningkatan yang hebat terutamanya dengan pembukaan tanah-tanah baru di Tawau.

Pada penghujung tahun 1918, kawasan tanaman mencapai 40,523 ekar termasuk milik pekebun kecil yang dianggarkan seluas 3,850 ekar. Pantai Timur menunjukkan jumlah peningkatan paling ketara iaitu meningkat kepada 4,299 ekar. Pantai Barat juga menunjukkan 
peningkatan yang banyak dengan mencatatkan jumlah kawasan 26,700 ekar. Manakala keluasan tanaman getah di Pedalaman, Sandakan dan Kudat masing-masing 3,800 ekar, 3,462 ekar dan 2,626 ekar. ${ }^{38}$ Pada tahun 1919, jumlah kawasan penanaman getah adalah sebanyak 47,739 ekar. Dalam tempoh setahun, pekebun kecil telah menggandakan jumlah penanaman. Kawasan yang dimiliki oleh mereka meningkat sekali ganda iaitu menjadi 7,578 ekar pada tahun 1919. Pantai Timur sekali lagi menunjukkan peningkatan sebanyak 3,147 ekar sekaligus menjadikan keluasan tanaman di kawasan itu menjangkau sehingga 7,446 ekar. Jumlah tanaman di Pantai Barat pula meningkat kepada 29,799 ekar manakala kawasan lain seperti Sandakan, Pedalaman dan Kudat hanya menunjukkan sedikit peningkatan. ${ }^{39}$

Pada tahap ini, sebahagian besar kawasan tanaman getah kebanyakannya dimiliki oleh syarikat-syarikat yang menerima jaminan dividen. Pada awalnya penanaman hanya tertumpu di Pantai Barat kerana kesesuaian tanahnya berbanding di Pantai Timur yang lebih sesuai untuk penanaman tembakau (terutamanya Lembah Segama). Pada tahun 1907, hanya satu per sepuluh getah ditanam di Pantai Timur tetapi menjelang pertengahan 1910-an, jumlah tersebut menunjukkan peningkatan yang ketara. Pada tahun 1921, Pantai Timur menunjukkan lebih daripada empat per sepuluh kawasan tanaman getah dan sebahagian besarnya dimiliki oleh pekebun kecil. Dalam tempoh lapan tahun (1912-1920), hanya tiga buah syarikat sahaja ditubuhkan. Sebahagian besar syarikat yang terlibat awal dalam industri pula telah menghentikan operasinya dan didapati hanya 18 buah syarikat sahaja yang beroperasi pada tahun 1921.

Sejak pertengahan tahun 1910-an, sebahagian besar perusahaan dimiliki oleh orang Eropah, pekebun kecil Cina dan tempatan. Pada tahun 1918, kawasan yang dimiliki oleh pekebun kecil ialah 3,850 ekar dan meningkat kepada 7,578 ekar pada tahun 1919. Pada masa ini, Beaufort mempunyai kawasan pekebun kecil paling besar iaitu 4,199 ekar. ${ }^{40}$ Pada ketika ini, bekalan buruh masih dipersoalkan terutamanya di Pantai Timur yang tanah-tanahnya baru dibuka. Di Pantai Barat pula beberapa penempatan besar berpotensi untuk mendapatkan buruh bagi keperluan di estet-estet sekitarnya. Misalnya North Borneo Trading Company memilih tanah di Tuaran dan Tenghelan untuk membuka estet kerana dipengaruhi oleh penempatan orang Kadazan dan Bajau di kawasan tersebut. Namun demikian, kadar kematian buruh yang tinggi akibat penyakit tropika (beri-beri, disenteri dan malaria) menyebabkan sesetengah syarikat menghadapi kelemahan dalam operasi mereka. ${ }^{41}$ 
Peta 1: Taburan Kawasan Penanaman Getah di Sabah pada tahun 1919.

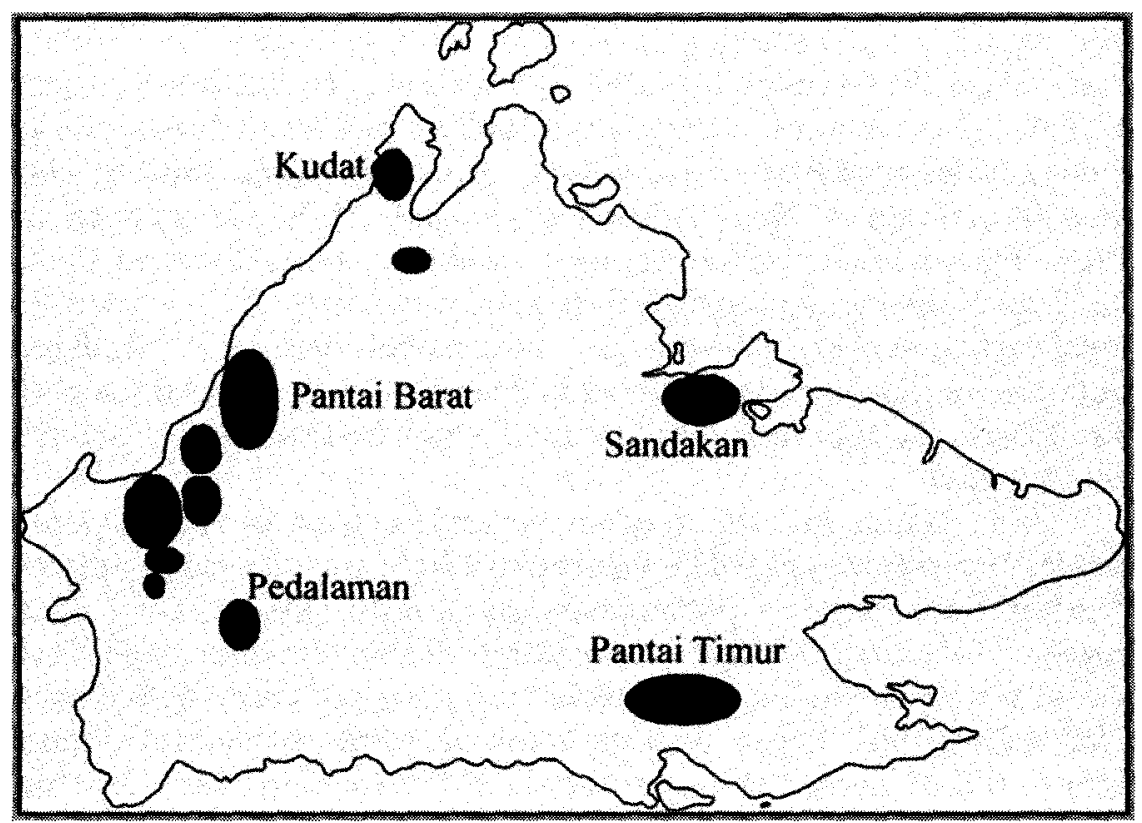

Sumber: Dilakar oleh penulis berdasarkan data yang diperolehi daripada Annual Report on Agriculture for 1919, British North Borneo Administration Report 1919, Printed At the Government Printing Office: Sandakan, Supplement to the Official Gazette.

\section{Kawasan Torehan dan Eksport Getah}

Pada tahun 1915, aktiviti menoreh getah terus diperluaskan. Kawasan yang menunjukkan kematangan semua pokok pada ketika itu ialah 9,806 ekar berbanding hanya 3,936 ekar tahun sebelumnya. Secara puratanya jumlah kawasan yang ditoreh dikebanyakan estet ialah 4,300 ekar dan purata hasil susu getah ialah 299 paun per ekar. ${ }^{42}$ Pada tahun 1918 , kawasan yang boleh ditoreh sepenuhnya ialah sebanyak 23,300 ekar sahaja. Hal ini menunjukkan bahawa berlaku pertambahan hampir 2,000 ekar berbanding tahun 1917 dan peningkatan ini didapati amat memberangsangkan. ${ }^{43}$ Aktiviti menoreh getah sangat pesat dan meningkat secara mendadak dan dalam tempoh setahun, jumlah kawasan yang ditoreh meningkat kepada 29,970 ekar pada tahun 1919.44 Peningkatan ketara ini disebabkan oleh kepesatan aktiviti penanaman sejak awal tahun 1910-an.

Sementara itu, eksport juga semakin meningkat berikutan kebanyakan pokok yang ditanam pada akhir tahun 1900-an telah ditoreh. Pada tahun 1915, eksport getah termasuk data yang dihantar 
oleh Jabatan Kastam kepada Jabatan Pertanian adalah sebanyak $2,135,500$ paun berbanding 1,226,000 paun pada tahun $1914 .{ }^{45} \mathrm{Jumlah}$ eksport meningkat kepada 4,888,000 paun pada tahun 1917 dan meningkat lagi kepada 5,187,000 paun pada tahun 1918. Jumlah ini menunjukkan peningkatan paling kecil kerana beberapa syarikat besar secara sukarela menghadkan pengeluaran bagi memberi sokongan kepada skim kawalan yang dilaksanakan oleh Persatuan Penanam Getah (Rubber Grower's Association). ${ }^{46}$ Pada tahun 1919, eksport getah meningkat kepada $8,823,422$ paun. ${ }^{47}$

Dalam fasa antara tahun 1915 sehingga akhir 1920, syarikatsyarikat di Pantai Barat menjadi penyumbang terbesar getah dari segi pengeluaran dan eksport. Misalnya, Sekong Rubber Company Limited telah mengeluarkan sebanyak 144,359 paun pada tahun 1915 dan jumlah tersebut meningkat berbanding tahun yang sebelumnya iaitu hanya 126,522 paun, ${ }^{48}$ Membakut Rubber Limited menghasilkan 133,340 paun, ${ }^{49}$ Kimanis Rubber Limited merekodkan keluaran sebanyak 118,521 paun, manakala Beaufort North Borneo Trust Limited menghasilkan 228,216 paun daripada 91,250 batang pokok getah pada tahun 1915-1916. Kualiti pengeluaran estet pada ketika ini sangat memuaskan dan berupaya memperoleh harga tinggi di pasaran apabila kualiti 85 peratus kepingan getah yang dihasilkan adalah gred pertama..$^{50}$ Sablas North Borneo Rubber Limited pula memulakan aktiviti menoreh pada tahun 1914-1915 dan meskipun kerja menoreh tergendala akibat kemarau teruk pada awal tahun 1915, namun mampu menghasilkan 160,953 paun getah. ${ }^{51}$ Secara keseluruhannya, jumlah kawasan tanaman getah di Sabah pada tahun 1915 berjumlah 12,564 ekar dengan eksport sebanyak 2,135,500 paun. Pada tahun 1920, jumlah ini semakin meningkat dengan jumlah tanaman sebanyak 20,989 ekar dan eksportnya sebanyak 9,195,435 paun. ${ }^{52}$

\section{Keuntungan Syarikat dan Bayaran Semula Dividen}

Bagi menggalakkan penanaman getah, kerajaan telah mengeluarkan wang sebanyak $£ 247,690$ sebagai jaminan dividen dan pinjaman tambahan sebanyak $£ 159,345$ pada tahun 1915 . Kerajaan juga memegang perkongsian dengan pelbagai syarikat perusahaan berjumlah $£ 268,353$. Namun, pelaksanaan dasar ini tidak memberikan kesan positif kepada semua syarikat pengusaha secara keseluruhannya. Jaminan dividen itu dibayar semula oleh syarikat-syarikat yang beroperasi kepada kerajaan dan ini telah mengurangkan keuntungan mereka pada tahun 1910-an. Pada tahun 1922, jumlah eksport getah menurun kepada 6,340,000 paun berbanding 9,195,435 paun pada tahun 1920. 
Antara syarikat perusahaan yang beroperasi secara bebas daripada jaminan dividen ialah British North Borneo Trading Company. Syarikat ini telah menubuhkan beberapa estet antara tahun 1909 dan 1911 iaitu Bode (1909), Lamag (1910), Tuaran (1910) dan Tenghelan (1911). Kesemua estet ini bersama dengan Estet Sekong mempunyai keluasan 8,389 ekar tetapi hanya 570 ekar ditanami getah pada tahun 1911. Pada tahun 1908, Estet Sekong menjadi sebuah badan perdagangan bebas sebanyak 70 peratus daripadanya dipegang oleh syarikat kerajaan. Begitu juga dengan Estet Bode dan Lamag yang diuruskan sepenuhnya oleh anak syarikat dan menerima jaminan dividen daripada kerajaan untuk beberapa tahun. ${ }^{53}$

Walaupun kebanyakan syarikat menikmati keuntungan memberangsangkan selepas perang berakhir, namun keuntungan tersebut tidak kesemuanya disimpan oleh syarikat pengusaha. Namun, sebahagiannya digunakan untuk membayar jaminan dividen kepada kerajaan. Misalnya, Sekong Rubber Company Limited yang menikmati keuntungan sebanyak $£ 2,385$ daripada 126,522 paun getah pada tahun 1914 terpaksa membayar semula jaminan dividen tersebut. ${ }^{54}$ Pada tahun berikutnya, syarikat ini meraih keuntungan sebanyak $£ 6,940$ kerana pengeluarannya bertambah dan harga bersih sedikit meningkat. Walau bagaimanapun, kos pengeluaran yang banyak terpaksa diganti oleh syarikat menyebabkan untung bersih berkurangan. ${ }^{55}$

Sementara itu, Tenom Rubber Company pula mencatatkan keuntungan sebanyak $£ 14,240$ pada tahun 1914 . Namun begitu, kesemua keuntungan ini tidak dinikmati kerana terpaksa membayar semula jaminan dividen sebanyak $2^{1 / 2}$ peratus daripada jumlah tersebut. ${ }^{56}$ Pada tahun 1915 , syarikat ini membayar sebanyak 20 peratus jumlah dividen daripada keuntungannya sebelum membawa $£ 14,000$ sebagai bayaran modal tahun berikutnya. ${ }^{57}$ Sementara itu, Membakut Rubber Limited menikmati keuntungan sebanyak $£ 4,333$ pada tahun 1915. Syarikat ini sebenarnya tidak lagi dibantu oleh jaminan dividen pada tahun 1910-an sebaliknya terpaksa bergantung kepada keuntungan yang diperoleh. ${ }^{58}$ Manakala Bode Rubber Estate pula mendapat keuntungan sebanyak $£ 1,120$ pada 31 Disember 1914. Daripada jumlah itu, komisen sebanyak $£ 872$ telah dipotong dan baki yang tinggal hanya $£ 247 . .^{59}$

Dalam masa yang sama, Beaufort Borneo Rubber Company Limited telah membuat bayaran semula sebanyak $£ 8,613$ kepada kerajaan. ${ }^{60}$ Marudu Rubber Limited pula mencatatkan keuntungan sebanyak $£ 4,955$ daripada 70,838 paun getah dan jaminan dividen yang dibayar semula adalah sebanyak $£ 2,355 .{ }^{61}$ Sementara itu, Estet Sablas yang memulakan aktiviti penorehan pada tahun 1914-1915 tidak menikmati keuntungan yang banyak akibat kemarau teruk melanda Sabah pada awal 1915 
sehingga estet tersebut hanya mampu menghasilkan 160,953 paun getah. ${ }^{62}$ Tenom Rubber Company pula agak menderita kerana tidak mampu memberi perhatian dalam aktiviti ekonomi. Selepas membayar 20 peratus jaminan dividen untuk tahun 1915, syarikat ini memperuntukkan $£ 14,000$ pula untuk bayaran modal tahun berikutnya. Selain itu, jumlah upah yang tinggi untuk semua kakitangan termasuk buruh mencapai sehingga 40 peratus. ${ }^{63}$ Maka sudah tentu keadaan ini mengurangkan lagi keuntungan yang dapat dinikmati oleh syarikat pengusaha.

\section{Perkembangan Getah dan Skim Kawalan, 1921-1941}

\section{Skim Sekatan Stevenson (1922-1928)}

Pada awal tahun 1920-an, kejatuhan harga getah berlaku lagi sehingga menyebabkan keadaan industri mencapai tahap paling membimbangkan. Harga pasaran dunia turun naik antara $£ 0.115$ dan E1.02 setiap paun dalam tempoh tahun 1914 sehingga tahun $1922 .{ }^{64}$ Terdapat beberapa faktor yang menyebabkan harga getah menurun misalnya serangan penyakit yang menyebabkan pokok-pokok getah di Brazil tidak mampu mengeluarkan hasil produktif. Perusahaan baru British dan Belanda di Tanah Melayu dan Indonesia juga menyebabkan stok keluaran semakin meningkat. Selain itu, kesan Revolusi Rusia (Oktober 1917) yang membuat getah sintetik daripada alkohol ethyl dan Treugolnik (projek Bogtayr) membawa kepada pengurangan permintaan getahnya daripada British. Ini menyebabkan banyak keluaran getah dunia menjadi beku dan lambakan stok semakin bertambah.

Pengeluar utama getah seperti Tanah Melayu, Ceylon, Hindia Timur Belanda, dan Borneo menunjukkan kebimbangan serius memandangkan komoditi ini merupakan sumber ekonomi terpenting. Di Sabah, segelintir pengusaha tidak lagi berupaya meneruskan perusahaan dengan modal sendiri melainkan hanya mengharapkan bantuan daripada kerajaan. ${ }^{55}$ Ketika industri sedang bergelut dengan masalah kejatuhan harga dan lambakan keluaran, kerajaan British mengambil inisiatif untuk mewujudkan jalan penyelesaian untuk menyiasat keadaan tersebut dengan menubuhkan satu jawatankuasa. ${ }^{66}$ Pada tahun 1920, Persatuan Penanam Getah British telah menemui Winston Churchill, Setiausaha Kolonial British untuk mendapatkan bantuan. Churchill menubuhkan Majlis Penyiasat dengan dianggotai oleh Persatuan Penanam Getah dan pengerusinya Sir James Stevenson. Mereka sebulat suara menjadikan badan ini sebagai satu rancangan menstabilkan harga getah di pasaran dengan menghadkan jumlah yang boleh dieksport oleh setiap wilayah pengeluar. Rancangan ini 
dilaksanakan mengikut Akta Stevenson dan Churchill bertanggungjawab mempengaruhi Parlimen British untuk meluluskannya sehingga menjadi satu enakmen pada bulan November $1922 .{ }^{67}$

Pada tahun 1922, British memegang sebanyak 72 peratus saham daripada pengeluaran getah dunia manakala Amerika Syarikat menggunakan 75 peratus keluaran getah dunia. Dalam pada itu, kerajaan British masih membayar hutang perang kepada Amerika Syarikat dan perlu mendapatkan keuntungan dalam industri getah. ${ }^{68}$ Belanda pula enggan menyertai Rancangan Stevenson kerana menganggap perkara tersebut tidak berdasarkan falsafah dan mereka tidak mahu keuntungan hanya dinikmati oleh British. ${ }^{69}$ Sebenarnya British melancarkan kaedah penyelesaian ini kerana bimbang mengenai kejatuhan industri tersebut akan menyebabkan hilangnya punca pendapatan memandangkan mereka merupakan pengeluar getah terbesar dunia. Skim Sekatan Stevenson bukanlah langkah kawalan yang pertama dilaksanakan berhubung dengan masalah kemelesetan harga getah.

Pada akhir tahun 1920, kerajaan British telahpun mengambil satu langkah untuk tujuan yang sama. Malah, Persatuan Penanam Getah di Britain turut melaksanakan kawalan pengeluaran getah sebanyak 25 peratus. Namun begitu, rancangan ini tidak berjaya kerana sokongan yang lemah daripada sebahagian besar penanam. Setiausaha Persatuan Penanam Getah, Frank G. Smith memaklumkan kepada ahlinya bahawa persatuan perlu mendapat persetujuan lebih 90 peratus daripada keahlian untuk mengawal pengeluaran sebanyak 25 peratus bagi tempoh 1 November 1921 sehingga 31 Disember 1921. Tambahan pula, terdapat penanam bukan ahli persatuan di United Kingdom yang mewakili 50,000 ekar tanaman memberikan sokongan kepada langkah ini. Selain itu, sokongan juga diperoleh daripada ahli Persatuan Antarabangsa di Hague (Belanda), pemilik tempatan di Ceylon, Persatuan Pengeluar Getah dan Persatuan Penanam Jepun di Malaya. Surat pekeliling bertarikh 13 Disember 1920 dihantar kepada semua pihak yang memberikan sokongan (kecuali pemilik di Ceylon) untuk mengawal secara drastik kebanyakan estet. ${ }^{70}$ Walau bagaimanapun, langkah ini tidak memperlihatkan kesan kepada industri dan memaksa Skim Sekatan Stevenson dilaksanakan.

Umumnya, matlamat utama skim ini telah meredakan kejatuhan harga getah akibat pengeluaran berlebihan ${ }^{71}$ dengan menetapkan kuota eksport yang dibenarkan untuk sesebuah negeri. Kuota yang dibenarkan untuk Sabah adalah sebanyak 60 peratus, namun akhbar British North Borneo Herald (BNBH) menyatakan bahawa kerjasama yang diberikan oleh syarikat-syarikat getah telah membantu 
meningkatkan eksport kepada 75 peratus ${ }^{72}$ Setelah skim dilaksanakan, berlaku sedikit perubahan dalam pasaran getah. Pada tahun 1923, stok getah di London dikurangkan sebanyak 12,500 paun dan sekurang-kurangnya 30,000 paun telah dikurangkan pada tahun 1924. Kesan skim kawalan ini amat dirasai dan ini merupakan langkah pertama yang berjaya dilakukan untuk mengurangkan lebihan tidak dikehendaki (unwanted surplus). ${ }^{73}$ Malah, semua pihak yang menyertai skim ini dilihat berjaya mengurangkan hutang dan turut berlaku sedikit peningkatan dari aspek keuntungan. ${ }^{74}$

Skim ini agak berjaya namun masalah timbul apabila pekebun kecil tidak mematuhi peraturan skim dan negara penanam besar seperti Indonesia tidak memberi sokongan. Skim Stevenson tergugat kerana kebanjiran getah yang dihasilkan oleh pekebun kecil di negara itu memberi kesan negatif kepada pasaran. Tambahan pula, pekebun kecil tidak perlu menampung kos pengurusan dan pengeluaran tinggi kerana mereka mempunyai kemahiran dan pengalaman menoreh yang diperoleh ketika bekerja dengan estet-estet besar. Majoriti pengusaha dan pemegang saham getah di Indonesia tidak menerima peraturan yang terkandung dalam skim. ${ }^{75}$ A kibatnya, negeri-negeri peserta menghadapi masalah kerana negara yang tidak menyertai skim terus menerus membuat pengeluaran tanpa kawalan. ${ }^{76}$

Pada tahun 1925, kerajaan Tanah Melayu terus mempertahankan Skim Stevenson dan menyatakan bahawa skim ini akan terus beroperasi sehingga tugasannya selesai. Secara mutlaknya, tidak wujud kebimbangan untuk melaksanakan skim ini supaya terus beroperasi walaupun terdapat propaganda atau campur tangan daripada pihakpihak tertentu. ${ }^{77}$ Sementara itu, Pengerusi Persatuan Penanam Getah, Eric Miller menyatakan bahawa pengalaman selama dua tahun skim itu dilaksanakan mengajar tentang keadilan serta menjadi alat pengukur trend pasaran yang tidak dapat dibayangkan selama ini. ${ }^{78}$ Kebanyakan pengusaha ladang pula percaya bahawa skim ini mampu memperbaiki harga pasaran dan dianggap sebagai penyelamat industri getah yang hampir tidak bergerak untuk beberapa ketika. Oleh itu, skim ini terus beroperasi dalam beberapa tahun lagi sebelum ditamatkan pada tahun 1928 selepas kerajaan British melakukan siasatan terperinci mengenainya. ${ }^{79}$ Ketika skim ditamatkan, eksport getah Sabah adalah sebanyak 15,033,412 paun dan jumlah keluasan tanaman adalah sebanyak 96,037 ekar. ${ }^{80}$

\section{Usaha Kawalan Persatuan Penanam Getah Sabah}

Keadaan pasaran yang dibanjiri pengeluaran getah dan harga rendah menyebabkan Persatuan Penanam Getah Sabah dengan kerjasama kerajaan melaksanakan kawalan pengeluaran iaitu pemberhentian 
penorehan sepanjang bulan Mei 1930. Kawalan ini bukanlah bersifat menyeluruh tetapi untuk memperlahankan pengeluaran berikutan keadaan harga pasaran yang tidak menentu selain mengelak pembaziran. Pada 11 April 1930, Setiausaha Persatuan Penanam Getah, Frank G. Smith telah menyatakan bahawa skim tersebut adalah khas untuk Persatuan Penanam Getah. Lebih daripada separuh ahli persatuan setuju menerima skim itu dan ianya akan beroperasi dalam tempoh yang ditetapkan. Dalam mesyuarat tahunan persatuan, pengerusinya menyatakan bahawa skim ini telah mendapat tindak balas luar biasa daripada pengeluar getah seluruh dunia. Pengeluar di United Kingdom memberi sokongan sebanyak 90 peratus manakala pengeluar di Indonesia menunjukkan sokongan sebanyak 91 peratus dan Tanah Melayu 79 peratus. ${ }^{81}$ Selain itu, sedikit sokongan juga diterima daripada penanam di Indochina manakala tindak balas daripada syarikat Eropah yang beroperasi di Ceylon amat sedikit walaupun jumlah keluaran negara itu tidak memberikan kesan yang besar kepada pengeluaran getah dunia.

Walaupun mendapat sokongan daripada pelbagai pihak, namun kerajaan perlu merujuk kepada para pengusaha di Sabah sendiri. Oleh itu, kakitangan kerajaan yang bertugas di setiap bahagian ditugaskan untuk mendapatkan tindak balas daripada pengusaha-pengusaha terlibat. Selepas kakitangan kerajaan mengambil kenyataan daripada pengusaha, maklumat baru yang diperolehi harus dihantar kepada kerajaan bagi memudahkan pelaksanaan skim ini. Pada 16 April 1930, Pemangku Residen di Pedalaman memaklumkan kepada kerajaan bahawa pengusaha getah di Pedalaman akan dipanggil untuk berjumpa dengan Residen serta ahli-ahlinya pada 15 dan 16 April 1930. Mereka dikehendaki menyokong pemberhentian penorehan itu kerana pekebun kecil di Tenom dan Pantai Barat telahpun menunjukkan sokongan. ${ }^{82}$ Surat untuk memastikan persetujuan mereka telah dihantar kepada pengurus Estet Melalap dan Estet Sapong tetapi kedua-duanya dikehendaki untuk memberikan keterangan lisan kepada Pegawai Daerah. $^{83}$

Pada 17 April 1930, Pemangku Setiausaha telah mengirimkan surat kepada gabenor A.F. Richards mengenai kawalan pengeluaran getah. Beliau menyatakan bahawa telah menerima surat daripada Persatuan Penanam Getah yang menyokong skim ini dan diterima daripada pelbagai pengeluar. Hanya tiga syarikat yang tidak bersetuju untuk mengikuti skim iaitu The North Borneo Rubber Limited, The Borneo Para Rubber Company Limited dan Lahad Datu Cultuur Maatschappij. Ketigatiga syarikat ini menyatakan bahawa mereka secara sukarela menerima kesan daripada kawalan "penggiliran merehatkan pokok" pada tahun 
$1928^{84}$ dan disebabkan oleh itu, mereka tidak setuju untuk menyertai skim tersebut. Malah, Bode Rubber Estate juga tidak menunjukkan sokongan terhadap skim ini.

Pemangku Residen menyatakan agak sukar untuk berhadapan dengan keengganan itu dan sukar untuk mengurangkan tekanan estet orang Eropah yang mengambil bahagian dalam skim. Oleh itu, adalah lebih baik sekiranya pegawai dibenarkan mengambil bahagian selanjutnya dalam organisasi skim. ${ }^{85}$ Dalam pada itu, Pemangku Residen juga telah memaklumkan Setiausaha Kerajaan bahawa satu perjumpaan telah diadakan di Chinese Chamber of Commerce Building, Sandakan dan dipengerusikan oleh F.W. Pinnock. Dalam perjumpaan tersebut, satu keputusan telah dicapai iaitu semua pengusaha getah di Sandakan sebulat suara menyokong skim tersebut. Di Tawau, hanya pekebun kecil seperti Wing Woo Cheong sahaja yang bersetuju menyertai skim ini. Residen Tawau memaklumkan kepada Setiausaha Kerajaan di Sandakan bahawa Pegawai Daerah Lahad Datu menyatakan ejen pengurusan Lower Segama Rubber Estate telah menerima arahan daripada Lembaga Getah untuk meneruskan penorehan pada bulan Mei. Pengurus Lahad Datu Cultuur Maatschappij pula bercadang untuk terus menoreh sehingga arahan bertentangan diterima. ${ }^{86}$

Terdapat juga beberapa syarikat yang tidak menunjukkan kerjasama misalnya North Borneo State Rubber, Beaufort Estate dan Trewalk Estate. Walaupun pekebun kecil sebulat suara menyokong skim ini namun pemilik yang bergantung sepenuhnya kepada hasil getah untuk meneruskan hidup dikecualikan untuk menyertainya. Sementara itu, sebanyak 72 keluarga Cina di bahagian utara telah bersetuju untuk menghentikan penorehan meskipun kebanyakannya hanya memiliki kawasan penanaman yang kecil. ${ }^{87}$ Hasil daripada sokongan-sokongan yang diperoleh, skim pemberhentian menoreh dilaksanakan sepanjang bulan Mei 1930. Skim yang dijalankan selama satu bulan ini tidak memberikan kesan yang membanggakan kerana tidak berjaya meningkatkan semula harga getah. Walau bagaimanapun, skim ini sedikit membantu mengurangkan keluaran getah Sabah pada waktu itu.

\section{Perjanjian Peraturan Getah Antarabangsa (IRRA)}

Pada tahun 1929, berlaku lagi kejatuhan harga getah sehingga memberi tamparan hebat kepada para pengusaha di Sabah. Pada masa ini, mereka hanya mengharapkan supaya skim kawalan lain dilaksanakan bagi meredakan kekecewaan terhadap skim sebelum ini. Keadaan ini menyebabkan banyak estet menghentikan pengeluaran dan menutup 
operasi pada tahun 1932. Meskipun eksport getah pada tahun tersebut menjangkau $12,000,000$ paun, namun hasilnya hanya $\$ 702,780$ berbanding $\$ 10,796,780$ untuk jumlah yang sama empat tahun sebelumnya. ${ }^{88}$

Pada tahun 1934, satu skim diwujudkan untuk mengatasi masalah tersebut iaitu Perjanjian Peraturan Getah Antarabangsa (International Rubber Regulation Agreement - IRRA). Skim ini memperuntukkan kuota asas untuk mengembalikan harga getah. Pekebun-pekebun kecil juga menderita sepanjang tempoh kejatuhan harga tetapi tidak setanding estet-estet besar yang memperuntukkan kos pengeluaran tinggi. Apabila rundingan dimulakan untuk mewujudkan skim ini, perhatian mula diberikan kepada pekebun kecil. Namun begitu, apabila skim dirangka pada Jun 1934, keluaran pekebun kecil dikawal sehingga mencapai purata 50 peratus. Oleh itu, skim kawalan tersebut menjadi kurang popular pada awal $1935 .{ }^{89}$ Kuota asas ditetapkan untuk jumlah tanaman dan eksport yang dibenarkan. Kuota ini terbahagi kepada dua iaitu "asas tetap" (purata eksport akan termasuk dalam tahun 1929-1932) dan "tambahan kepada asas tetap" (skala kawasan penanaman yang dibenarkan dalam tempoh 1921-1931). Hasil kuota asas untuk Sabah bagi setiap lima tahun adalah seperti berikut:

Jadual 2: Kuota asas yang ditetapkan untuk Borneo Utara dalam masa lima tahun.

\begin{tabular}{|cccc|}
\hline Tahun & $\begin{array}{c}\text { Asas Tetap } \\
\text { (Tan) }\end{array}$ & $\begin{array}{c}\text { Tambahan kepada } \\
\text { Asas Tetap (Tan) }\end{array}$ & $\begin{array}{c}\text { Jumlah } \\
\text { (Tan) }\end{array}$ \\
\hline 1934 & 6,525 & 5,475 & 12,000 \\
1935 & 6,525 & 6,475 & 13,000 \\
1936 & 6,525 & 7,475 & 14,000 \\
1937 & 6,525 & 8,975 & 15,500 \\
1938 & 6,525 & 9,975 & 16,500 \\
\hline
\end{tabular}

Sumber: S/F 1455C, (G.S.O. No. 00151) Memorandum Sulit bertajuk "North Borneo Claim for Additional Rubber Quota Recopitulated and Reconsider in the Light of the Decisions Taken on the $20^{\text {th }}$ November by the International Rubber Regulation Committee", hlm. 2.

Eksport asas tetap dihitung dengan mengambil kira jumlah pengeluaran dari tahun 1929 sehingga tahun 1932. Semua pengeluar menghasilkan 26,111 tan dengan purata pengeluaran 6,528 tan setiap tahun. Mengikut statistik data yang dikeluarkan oleh Jabatan Pertanian, getah yang ditanam pada akhir tahun 1924 hingga 1927 mulai ditoreh selepas mencapai usia antara empat hingga lima tahun. Dalam jangka 
masa ini, aktiviti menoreh pokok muda ditangguhkan sehingga mencapai tahap matang. Ini kerana, kos torehan pokok muda lebih tinggi dan hasil torehan tidak akan dibayar apabila harga getah rendah. Jumlah pokok yang telah ditoreh sebelum tahun 1929 tidak dimasukkan dalam rekod jumlah pengeluaran kerana beberapa estet orang Eropah telah menghentikan aktiviti menoreh dalam masa berbeza antara tahun 1929 hingga 1932. ${ }^{90}$ Antara estet tersebut ialah Bongawan, Batu Lima, Bukit Padang, Kinarut, Langkon, Lower Segama, Lumat, Mandahan, Mawao, Mambakut, Papar, Pitas, Sapong, Sekong, Sungai Batang, Taritipan dan Tenghilan. Keluasan estet-estet ini adalah sebanyak 42 peratus daripada jumlah keseluruhan kawasan yang ditanam oleh syarikat Eropah dan pemilik Jepun.

Selain itu, terdapat juga sesetengah estet yang meneruskan penorehan misalnya Estet Kuhara dan Estet Kubota. Manakala estetestet lain pula membiasakan amalan torehan terpilih dimana pokokpokok yang kurang memberikan hasil tidak akan ditoreh bagi mengurangkan kos pengeluaran. Walau bagaimanapun, perkara ini telah mendapat tentangan kerana eksport getah dalam jangka masa tahun 1929-1932 seharusnya menjadi rujukan bagi melihat kemampuan Sabah bersaing dalam pasaran getah antarabangsa. Oleh itu, syarikat yang cuba mengecualikan estet mereka daripada melakukan torehan akan dilupuskan modalnya. Sebenarnya, estet yang merehatkan torehan pokok getah bukan kerana terpaksa sebaliknya mereka cuba melindungi dan meningkatkan simpanan mereka. Misalnya, pemilik Estet Kuhara dan Estet Kubota di Tawau disekat daripada menoreh berdasarkan perbandingan usia pokok yang ditoreh dan bukannya mereka tidak mampu mengeluarkan modal. ${ }^{91}$

Pada 14 November 1933, satu Sub-Jawatankuasa Wilayah Tanah Melayu melaporkan bahawa Jawatankuasa Peraturan Getah daripada Persatuan Penanam Getah mengesyorkan penyesuaian harga tetap kepada pengeluar individu diikuti dengan kiraan kuota antarabangsa. Ini menuntut supaya pengeluar mengurangkan pengeluaran dengan lebih banyak berbanding purata pengeluaran 1929-1932. Oleh itu, penangguhan torehan awal perlu dilakukan supaya pokok mencapai tahap matang sebelum ditoreh. Langkah ini dilaksanakan di Sabah bagi menyesuaikan jumlah pengeluarannya dengan negeri-negeri lain dan juga untuk melihat sejauh mana keberkesanan pelaksanaan dasar tersebut. Sabah seharusnya diberikan kebenaran untuk menetapkan pengeluaran kepada 9,000 tan setahun. Dalam jangka masa 1929-1932, jumlah yang diperoleh dari kawasan boleh ditoreh ditunjukkan dalam jadual berikut: 
Jadual 3: Jumlah kawasan yang boleh ditoreh dan jumlah tan yang diperoleh dalam jangka masa 1929-1932.

\begin{tabular}{|ccc|}
\hline Tahun & $\begin{array}{c}\text { Kawasan yang } \\
\text { boleh ditoreh }\end{array}$ & $\begin{array}{c}\text { Tanaman @ 265 paun } \\
\text { (per ekar) }\end{array}$ \\
\hline 1929 & 62,268 ekar & 7,381 tan \\
1930 & 70,466 ekar & 8,350 tan \\
1931 & 81,013 ekar & 9,600 tan \\
1932 & 90,490 ekar & 10,723 tan \\
\hline & Jumlah & 36,054 tan $/ 4=9,013$ tan \\
\hline
\end{tabular}

Sumber: S/F 1455C, (G. S. O. No. 00151) Memorandum Sulit bertajuk "North Borneo Claim for Additional Rubber Quota Recopitulated and Reconsider in the Light of the Decisions Taken on the $20^{\text {th }}$ November by the International Rubber Regulation Committee", hlm 6.

Jumlah ini memberi potensi produktif apabila kadar 265 paun ditetapkan untuk setiap ekar. Namun begitu, lebihan akan berlaku sekiranya penorehan pokok yang matang tidak ditangguhkan..$^{92}$ Oleh itu, penangguhan menoreh getah muda perlu dilakukan agar keluaran lebih produktif. Bagaimanapun, sesetengah penanam baru yang mempunyai pokok getah bertunas dibenarkan menoreh dalam kadar lebih tinggi. ${ }^{93}$ Pada dasarnya, anggaran dan kuota hanya diberikan kepada negeri yang telah menandatangani perjanjian. Di Sabah, kuota yang diberikan sedikit jatuh daripada purata sepatutnya iaitu sebanyak 4,800 tan setahun. Kedudukan ini bertambah buruk pada tahun 1936 apabila kuota asas dikurangkan daripada 14,000 tan kepada 13,020 tan. Hal ini adalah berikutan Perjanjian Antarabangsa yang ditandatangani antara India, Burma, Siam dan Hindia Timur Belanda. Keadaan ini menimbulkan rasa tidak puas hati dalam kalangan pengeluar-pengeluar di Sabah kerana pada dasarnya langkah tersebut difikirkan mampu menambah kuota asas tetapi sebaliknya pengeluaran negeri tersebut merundum. Ini menyebabkan para pengeluar menentang skim ini. ${ }^{94}$

Keadaan tersebut tidak meyakinkan kerana Sabah masih boleh mengeksport getah dengan jumlah yang banyak walaupun potongan antarabangsa dilaksanakan sebanyak 40 peratus. Selain itu, percanggahan tidak jelas antara jumlah eksport Sabah dengan eksport rendah yang dibenarkan untuk estet-estet getah juga menimbulkan keraguan kepada para pengeluar. Mereka kemudiannya menyatakan bahawa kesilapan tersebut berlaku kerana pentadbiran peringkat tempatan lebih menumpukan keutamaan kawalan kepada pekebunpekebun kecil. Berdasarkan kuota asas yang dibenarkan, Sabah telah 
menghasilkan 20,600 tan pada tahun 1935 dan meningkat kepada 25,400 tan pada tahun 1938.

Kemuncak kesukaran kawalan yang dilaksanakan oleh IRRA bukan hanya tertumpu kepada pengeluaran hasil yang dikeluarkan oleh para pengusaha getah sebaliknya tertumpu kepada jumlah eksport. Pada tahun 1934, pengeluaran dihadkan kepada 1,019,000 tan sebelum meningkat kepada 25 peratus pada tahun 1938. Pada tahun pertama kuota itu dilaksanakan, pengeluaran dari Tanah Melayu ialah 504,000 tan, Indonesia 352,000 tan, Ceylon 77,000 tan, Sarawak 24,000 tan, Siam 15,000 tan, Sabah 12,000 tan, India 6,850 tan dan Burma 5,150 tan. Secara praktiknya, penanaman baru ini tidak dibenarkan manakala hanya 20 peratus sahaja penanaman semula dibenarkan. Sementara itu, eksport benih getah ke kawasan penanaman berpotensi dilarang untuk dijalankan. ${ }^{95}$

IRRA telah diperbaharui pada 6 Oktober 1938 dan berkuatkuasa sehingga 31 Disember 1943. Pembaharuan itu menyebabkan kuota pengeluaran getah Sabah dipertingkatkan daripada 16,500 tan kepada 21,000 tan pada tahun 1939. Walau bagaimanapun, penambahan keluasan kawasan tanaman tidak dibenarkan. Ini merupakan dasar yang kurang adil kerana negara-negara peserta yang lain tidak dikenakan sekatan yang sama. ${ }^{96}$ Meskipun demikian, satu peraturan baru telah dikeluarkan iaitu memberi kebenaran kepada estet-estet untuk meluaskan tanaman tidak melebihi 5 peratus daripada jumlah keseluruhan kawasan tanaman mereka. Hasilnya, kuota pengeluaran getah Sabah meningkat secara perlahan-perlahan berdasarkan peningkatan harga dan keadaan pasaran yang semakin menggalakkan.

Sekiranya dilihat kepada perkembangan yang berlaku, kerajaan sepatutnya menikmati keuntungan yang tinggi berdasarkan jumlah eksport dan pendapatan yang diperoleh pada tahun 1940 apabila Sabah berjaya mengeksport sebanyak $39,474,026$ paun getah dengan pendapatan sebanyak $\$ 14,444,759$. Namun, kerajaan hanya menikmati keuntungan tersebut dalam masa yang singkat kerana telah mengecualikan levi eksport kepada pengusaha yang beroperasi di bawah skim jaminan dividen. Walaupun demikian, IRRA berjaya memberi kesan positif kepada industri penanaman getah di Sabah sehingga jumlah keluasan tanaman mencapai 133,000 ekar iaitu 74,000 ekar dimiliki oleh estet dan 59,000 dimiliki oleh pekebun kecil. ${ }^{97}$ Berdasarkan peta di bawah, taburan penanaman getah di Sabah pada ketika ini masih lagi didominasi oleh kawasan Pedalaman dan Pantai Barat yang menjadi pusat perkembangannya pada peringkat awal. Menjelang tahun 1941, keadaan industri menunjukkan perkembangan 
yang positif dan mula memberi pulangan memberangsangkan kepada para pengusaha yang beroperasi.

Peta 2: Taburan Penanaman Getah di Borneo Utara pada tahun 1940.

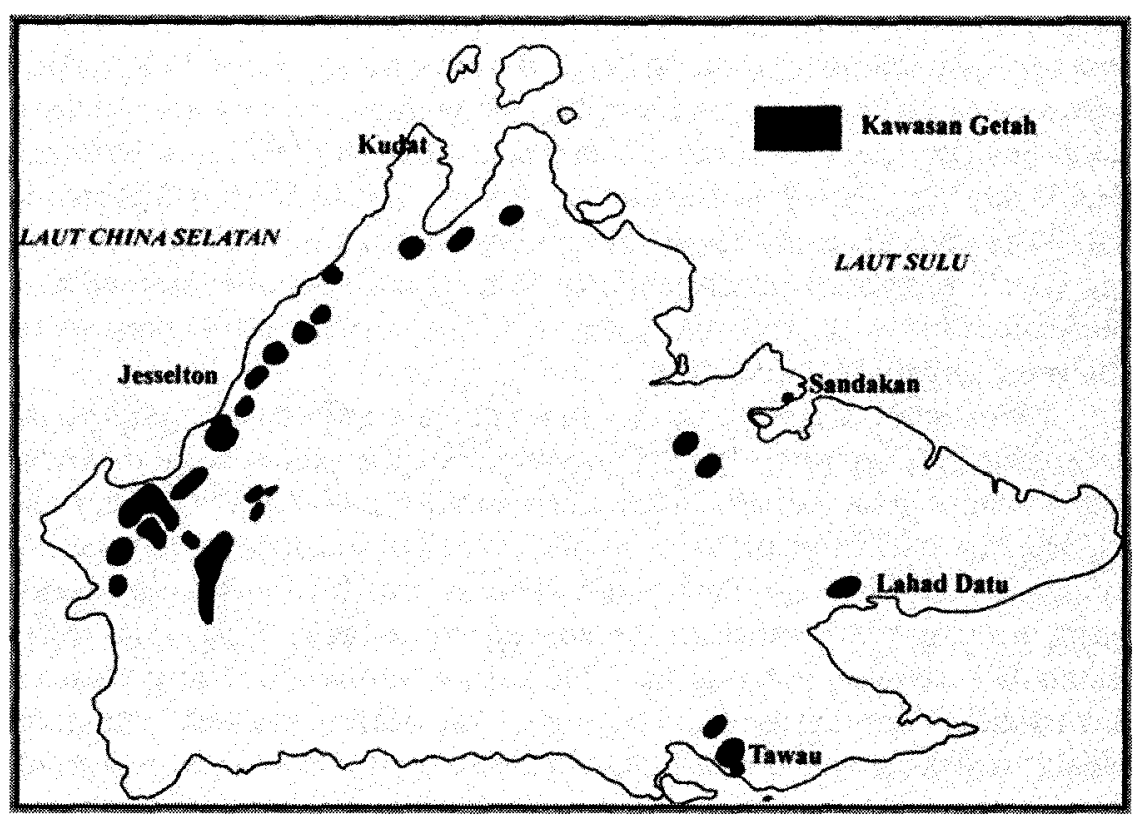

Sumber: Amarjit Kaur, Economic Change in East Malaysia: Sabah and Sarawak Since 1850, London: Macmillan Press Ltd., 1998, hlm. 47. (Lakaran semula).

\section{Kesimpulan}

Selepas ujian benih getah dilakukan, ternyata tanaman ini sesuai ditanam secara komersil dan beberapa pihak telah membuat percubaan untuk menanamnya. Tanaman ini mempunyai kelebihan berbanding tembakau misalnya cepat memberikan hasil dan penjagaan yang lebih mudah. Keadaan ini mendorong pembukaan kawasan penanaman yang lebih luas. Insentif jaminan dividen dan pengecualian duti eksport selama 50 tahun ternyata menarik banyak syarikat melibatkan diri dalam industri dan penanaman getah turut menggalakan pembinaan landasan keretapi dari Pantai Barat ke kawasan pedalaman. Dalam tempoh 1905 sehingga perang dunia meletus, penanaman getah di Sabah amat menggalakkan apabila para pengusaha semakin meluaskan tanaman dan kerajaan pula menjual tanah kepada syarikat-syarikat pengusaha. Selepas satu dekad, para penanam dan pelabur mampu 
menikmati keuntungan yang lumayan. Walau bagaimanapun, kebanyakan mereka mengalami kerugian apabila perang meletus (1914) kerana hasil getah tidak dapat dieksport ke Eropah akibat dibekukan di pelabuhan-pelabuhan. Selepas perang, industri ini kembali rancak dan satu fenomena baru berlaku iaitu kemunculan pekebun kecil dan tempatan. Mereka menjadi saingan utama kepada syarikat-syarikat yang beroperasi pada ketika itu. Meskipun industri semakin berkembang, namun kejatuhan harga berlaku semula pada penghujung tahun 1920. Oleh itu, Skim Sekatan Stevenson (1922-1928) dilaksanakan untuk mengatasi masalah tersebut. Bagaimanapun, perkembangan industri agak mengecewakan kerana pengeluar besar tidak memberi sokongan dan keluaran getah dalam pasaran terus bertambah.

Sekitar tahun 1929-1933, ekonomi dunia mengalami kemelesetan sehingga harga getah turun sehingga tahap paling rendah dalam sejarah. Keadaan ini memaksa Persatuan Penanam Getah memikirkan cara untuk meningkatkan semula harga pasaran dengan mengawal pengeluaran getah di negara-negara pengeluar. Pelaksanaan IRRA pada tahun 1934 secara langsung berjaya mengubah keadaan tersebut apabila kuota pengeluaran untuk setiap pengeluar telah ditetapkan. Walaupun segelintir pengusaha di Sabah tidak berpuas hati dengan dasar-dasar IRRA, namun secara keseluruhannya kerajaan mendapat faedah daripadanya kerana mampu memberi keuntungan kepada industri. Secara keseluruhannya, aktiviti penanaman getah di Sabah telah memberi keuntungan lumayan kepada kerajaan. Sebagai sebuah badan pentadbir, kerajaan menggunakan pendapatannya untuk membangunkan negeri.

Pembinaan landasan keretapi, jalanraya dan pelabuhan lebih pesat berlaku kerana kemudahan-kemudahan ini digunakan untuk melicinkan urusan industri dan secara tidak langsung berfungsi sebagai alat perhubungan. Satu kesan sosial yang amat jelas adalah berlaku juga pertambahan penduduk. Keperluan buruh untuk bekerja di estet-estet getah menuntut kegiatan import tenaga kerja dari China dan Pulau Jawa dilakukan. Langkah ini bukan sahaja membantu perkembangan industri getah malah turut meningkatkan jumlah penduduk. Kesan daripada perkembangan industri ini, perubahan ketara dalam aspek ekonomi, infrastruktur dan demografi juga dapat dilihat.

\section{Nota}

K.G. Tregonning, A History of Modern Sabah: North Borneo, 1881-1963, Singapore: University of Malaya Press, 1965, hlm. 93-94. 
S/F 1423, Report on The Agricultural Prospects of British North Borneo by L. B. Von Donop, hlm. 8.

BNBH, Mac 1886, hlm. 143.

Baker, Michael H., Sabah The First Ten Years As A Colony 1946-1956, University of Singapore: Malaysian Publishing House for The Department of History, 1965, hlm. 103.

5 Kuat Kwai Fong, Perkembangan Ekonomi Ladang Di Sabah 1881-1941, Kuala Lumpur: Jabatan Sejarah, Fakulti Sastera dan Sains Sosial, Universiti Malaya, 1996, hlm. 167.

British North Borneo Herald, 16 September 1899, hlm. 279.

Handbook Of The State Of North Borneo, London: The British North Borneo Chartered Company, 1934, hlm. 67.

$8 \quad$ Kuat Kwai Fong, Perkembangan Ekonomi Ladang, hlm. 167-168.

9 S/F 1455C, (G.S.O. No. 00151) Memorandum Sulit bertajuk "North Borneo Claim for Additional Rubber Quota Recopitulated and Reconsider in the Light of the Decisions Taken on the $20^{\text {th }}$ November by the International Rubber Regulation Committee", hlm. 1.

10 Kuat Kwai Fong, Perkembangan Ekonomi Ladang, hlm. 168.

11 Handbook Of The State Of North Borneo, 1934, hlm. 67.

12 British North Borneo Herald, 1 Februari 1917, hlm. 27.

13 Kuat Kwai Fong, Perkembangan Ekonomi Ladang, hlm. 168.

14 British North Borneo Herald, "Tenom Rubber", Jun 1908, hlm. 109.

15 Jagir Singh, The Geographic Impact Of Foreign Assistance On The Growth Of Indonesian's Rubber And Petroleum Industry, London: University Microfilm International, 1979, hIm. 259.

16 Handbook Of The State Of North Borneo, 1934, hlm. 68.

17 Pada awal abad ke-20, penanaman getah berlaku dengan cepat akibat perkembangan industri automobil di samping kenaikan harga getah di pasaran dan penawarannya pula kurang. Keadaan ini menyebabkan penanaman getah asli dalam skala yang besar berlaku di Asia Selatan dan Asia Tenggara. Lihat Lim Swee Aun, Rubber And The Malaysian Economic: Implication of Declining Prices, Ohio University: International Studies, 1969, hlm. 1. Jumlah pengeluaran kenderaan bermotor di Amerika Syarikat meningkat dengan banyak dalam masa beberapa tahun iaitu 4,192 buah pada tahun 1900 menjadi 24,250 pada tahun 1905. Di samping itu, pengeluaran trak dan bas juga sedang diusahakan dengan pengeluaran awal sebanyak 750 buah pada tahun 1905. Lihat J.H. Drabble, Rubber In Malaya 1876-1922: The Genesis of The Industry, hlm. 224.

18 Voon Phin Keong, Western Rubber Planting Enterprise in Southeast Asia 1876-1921, Kuala Lumpur: Penerbit Universiti Malaya, 1976, hlm. 108.

19 K.G. Tregonning, Under Chartered Company (North Borneo 1881-1946), Singapore: University of Malaya Press, 1958, hlm. 89. Lihat juga Kuat Kwai Fong Perkembangan Ekonomi Ladang Di Sabah 1881-1941, hlm. 173.

20 Voon Phin Keong, Western Rubber Planting Enterprise, hlm 108.

21 Handbook Of The State Of North Borneo, 1934, hlm. 67-68. 
22 S/F 1423 "Planting in British North Borneo", Printed at Government Printing Office British North Borneo, Sandakan, 1907, hlm. 10.

23 Ibid., hlm. 10.

24 Kenyataan ini bercanggah dengan kenyataan yang diberikan oleh Kuat Kwai Fong dalam tesis sarjananya bertajuk "Perkembangan Ekonomi Ladang Di Sabah 1881-1941". Beliau menyatakan bahawa keluasan tanah yang dimiliki oleh Beaufort Rubber Company ialah sebanyak 8,000 ekar, manakala North Borneo State Rubber Company pula mempunyai konsesi tanah seluas 5,000 ekar.

25 Voon Phin Keong, Western Rubber Planting Enterprise, hlm. 110.

26 Ian Black, A Gambling Style of Government: The Establishment of Chartered Company Rule in Sabah 1878-1915, Kuala Lumpur: Oxford University Press, 1983, hlm. 209.

27 Projek pembinaan landasan keretapi dari Pantai Barat ke Pedalaman telahpun dipertimbangkan sejak tahun 1891 apabila terma tersebut cuba diaturkan dengan syarikat persendirian. Walaupun, tidak ramai yang memberikan sokongan terhadap rancangan ini, namun syarikat persendirian merasakan bahawa rancangan ini berfaedah untuk kerajaan khususnya meningkatkan aktiviti import dan eksport. Lihat British North Borneo Herald, 16 November 1896, hlm. 23. Pada tahun 1896, cadangan itu sekali lagi dikemukakan oleh William Clarke Cowie kerana Borneo Utara mempunyai bentuk muka bumi bergunungganang dan lebih baik jika landasan keretapi dibina terlebih dahulu sebelum membina jalanraya. Tambahan pula, pengangkutan ini mampu memberikan sumbangan besar dalam ekonomi kerana berupaya mengangkut banyak komoditi perdagangan yang dihasilkan di sekitar Pantai Barat dan Pedalaman. Cowie berjaya memujuk Lembaga Pengarah SBBU di London supaya membina landasan keretapi yang menghubungkan Teluk Kimanis-Beaufort. Tanggungjawab pembinaan landasan keretapi telah diserahkan kepada Mr. West iaitu seorang jurutera koloni British. Pembinaan landasan tersebut meliputi Bakau yang terletak lapan batu dari Weston dan berjaya diselesaikan pada tahun 1900. Landasan keretapi sepanjang 57 batu dari Jesselton ke Beaufort telah berjaya disiapkan pada tahun 1902 dan 30 batu lagi disambungkan ke Tenom-Padas Gorge. Landasan ini siap pada tahun 1905 dan kemudian disambung sehingga ke Melalap melalui Keningau. Perkembangan pesat pembinaan landasan keretapi di Borneo Utara membawa kepada penubuhan The Sabah State Railway pada tahun 1910. Hanizah $\mathrm{Hj}$. Idris, Perkembangan Perdagangan, Perkapalan dan Pelabuhan di British Borneo 1800-1963, Kuala Lumpur: Penerbit Universiti Malaya, 2006, hlm. 197198.

28 K.G. Tregonning, Under Chartered Company (North Borneo 1881-1946), hlm. 89.

29 British North Borneo Herald, 1 Februari 1917.

30 Kuat Kwai Fong, Perkembangan Ekonomi Ladang Di Sabah 1881-1941, hlm 197. Buruh cina menjadi pilihan untuk berkerja di estet-estet kerana 
mereka mempunyai susuk badan yang lebih besar dan mereka merupakan buruh terbaik di Asia serta mudah diperolehi. Mereka lahir sebagai petani, pandai berjimat, dan juga rajin melakukan kerja. Selain itu, mereka juga mampu bertahan dengan pertukaran iklim dan telah terbukti mampu memberi faedah yang sangat besar kepada negara yang merekrut mereka menjadi buruh. Secara umumnya, kebanyakan buruh Cina ini direkrut dari wilayah berdekatan dengan Swatow yang mengandungi suku bangsa seperti Teo Chew, Hylockongs, Kehs, Macaoes dan Hokkien. Lihat British North Borneo Herald, 16 Mac 1916, hlm. 103.

31 Kuat Kwai Fong, Perkembangan Ekonomi Ladang Di Sabah 1881-1941, hlm 198. Estet-estet di Borneo Utara memerlukan perbelanjaan yang tinggi untuk menanggung kos mendapatkan buruh. Hal ini kerana buruh Cina amat sukar diperolehi akibat keengganan mereka untuk menjadi buruh estet-estet getah di Borneo Utara. Bagi imigran-imigran Cina, mereka mendapati bahawa Borneo Utara kurang popular sebagai tempat bermastautin berbanding tempat lain misalnya Tanah Melayu dan Singapura. Oleh itu, tidak hairanlah jika kawasan yang berdekatan dengan Singapura menjadi impian buruh-buruh dari China. Pulau Jawa merupakan sumber bekalan buruh kedua bagi Borneo Utara dan mereka direkrut untuk kontrak kerja selama dua tahun. Oleh kerana kos mengimport buruh Jawa lebih tinggi maka jumlah mereka hanya 4,495 pada tahun 1914-1921. Sementara itu, buruh India pula lebih suka kepada prospek ekonomi yang lebih cerah seperti di Ceylon, Tanah Melayu dan Burma. Perkara ini berlaku kerana tempat-tempat tersebut lebih hampir dengan tanahair mereka berbanding Borneo Utara. Tambahan pula, tidak ada langkah serius yang diambil oleh kerajaan untuk mendapatkan buruh Tamil. Buruh tempatan pula diperoleh dari Pedalaman terutamanya dari Keningau dan Tambunan. Dari tahun 1911, pemuda dari dua daerah tersebut mula berhijrah ke Pantai Barat untuk berkerja di estet-estet kerana hasil tuaian tanaman mengecewakan akibat kemarau panjang di Pedalaman. Lihat D.S. Ranjit Singh, The Making Of Sabah: The Dynamics of Indigenous Society, Kuala Lumpur: University Malaya Press, 2003, hlm. 246.

32 British North Bomeo Herald, 1 Februari 1917, hlm. 28.

33 Perang Dunia Pertama berlaku antara 28 Julai 1914 hingga 11. November 1918 dan bermula di Balkan. Perang ini berlaku disebabkan oleh faktor politik dan ekonomi. Antara faktor politik termasuklah kemunculan nasionalisme dan sistem pakatan negara-negara Eropah, iaitu Perikatan Kuasa Tengah dan Pakatan Bertiga. Faktor ekonomi pula melibatkan persaingan kuasa-kuasa besar merebut peluang ekonomi. Pada penghujung abad ke-19, negara-negara kecil di Eropah telah bersatu dan membentuk sebuah negara bangsa yang lebih besar misalnya Jerman dan Itali. Kedua-dua negara ini menyertai kuasa besar Eropah yang lain seperti Britain, Perancis, Austria-Hungary dan Rusia dalam usaha mendapatkan tanah jajahan. Nasionalisme yang kuat menyebabkan kuasa-kuasa besar ini sanggup berperang bagi 
membuktikan kekuasaan masing-masing. Menjelang penghujung abad ke-19 dan awal abad ke-20, persaingan sengit berlaku di kalangan kuasa Eropah ini menyebabkan Imperialisme baru. Kuasa besar mula bersaing bagi membentuk lingkungan pengaruh masing-masing untuk mendapatkan bahan mentah serta memasarkan barangan siap mereka. 34 British North Borneo Herald, 16 September 1915, hlm. 176.

35 British North Borneo Herald, 16 September 1916, hlm. 3.

36 Kerajaan telah mengeluarkan bayaran jaminan dividen sebanyak $£ 247,690$ pada tahun 1915 dan $£ 159,345$ ditambah sebagai pinjaman. Dasar ini banyak membantu syarikat pengusaha untuk meningkatkan aktiviti di estet mereka. Walau bagaimanapun, dasar tersebut tidaklah memberi kesan positif kepada industri secara keseluruhannya kerana dividen yang diberikan oleh kerajaan telah dibayar semula oleh kebanyakan syarikat dan ini telah mengurangkan keuntungan kerajaan pada tahun 1910-an. Lihat Voon Phin Keong, Western Rubber Planting Enterprise in Southeast Asia 1876-1921, hlm. 111.

37 Annual Report on Agriculture For 1915, British North Borneo Administration Report 1915, Printed At The Government Printing Office: Sandakan, Supplement To The Official Gazette, 1 February 1916, hlm 88. Lihat juga British North Borneo Herald, 1 Februari 1917, hlm. 21.

38 Annual Report on Agriculture For 1918, British North Borneo Administration Report 1918, Printed At The Government Printing Office; Sandakan, Supplement To The Official Gazette, hlm. 83.

39 Annual Report on Agriculture For 1919, British North Borneo Administration Report 1919, Printed At The Government Printing Office: Sandakan, Supplement To The Official Gazette, hlm. 85.

40 Annual Report on Agriculture For 1919, hlm. 85.

41 Voon Phin Keong, Western Rubber Planting Enterprise, hlm. 114.

42 Annual Report on Agriculture For 1915, hlm. 88.

43 Annual Report on Agriculture For 1918, hlm. 83.

44 Annual Report on Agriculture For 1919, hlm, 85

45 Annual Report on Agriculture For 1915, hlm. 88

46 Annual Report on Agriculture For 1918, hlm. 83.

47 Annual Report on Agriculture For 1919, hlm. 85.

48 British North Borneo Herald, 16 Februari 1916, hlm. 32

$49 \quad$ Ibid., hlm. 33-34.

$50 \quad$ British North Borneo Herald, 16 Oktober 1916, hlm. 180.

51 British North Borneo Herald, 2 Disember 1916, hlm. 211.

52 Amarjit Kaur, Economic Change in East Malaysia: Sabah and Sarawak Since 1850, London: Macmillan Press Ltd., 1998, hlm. 43.

53 Voon Phin Keong, Western Rubber Planting Enterprise in Southeast Asia 1876-1921, hlm 111.

54 British North Borneo Herald, 1 Februari 1915, hlm. 23.

55 British North Borneo Herald, 16 Februari 1916, hlm. 32.

56 British North Borneo Herald, 1 Julai 1915, hlm. 127.

57 British North Borneo Herald, 1 Februari 1917, hlm. 28.

58 British North Borneo Herald, 16 Februari 1916, hlm. 33-34. 
British North Borneo Herald, 16 Ogos 1916, hlm. 4.

British North Borneo Herald, 16 Oktober 1916, hlm. 180.

British North Borneo Herald, 2 Disember 1916, hlm. 210.

Ibid., hlm. 211.

British North Borneo Herald, 1 Februari 1917, hlm. 28.

4 D. Warren, Brazil and the Struggle for Rubber: A Study in Environmental History, Cambridge: Cambridge University Press, 1987, hlm. 105.

65 British North Borneo Herald, Januari 1922, hlm. 13.

66 Kuat Kwai Fong, Perkembangan Ekonomi Ladang, hlm. 293.

67 Garth Cant, An Historical Geography of Pahang, "The Federated Malay States Passed the Export of Rubber (Restriction) Enactment", Printed for the MBRAS by Times Printers, 1972, hlm. 111.

68 The Time Magazine "Rubber Restricted", 7 May 1934.

69 Selain kedegilan Belanda untuk menyertai Skim Stevenson, terdapat juga halangan hebat yang datang daripada pengeluar tempatan yang beroperasi di wilayah-wilayah pengeluar yang lain. Sementara itu, di Amerika Syarikat pembuat tayar, Harvey Firestone menunjukkan reaksi tidak puas hati terhadap akta yang dibuat oleh Setiausaha Perdagangan, Herbert Hoover.

70 The New York Times, 26 Oktober 1921.

71 British North Borneo Herald, "Rubber Restriction", 16 Januari 1925, hlm. 8 .

72 Kuat Kwai Fong, Perkembangan Ekonomi Ladang Di Sabah 1881-1941, hlm. 295.

7.3 British North Borneo Herald, "Improving Rubber Prospects" 16 Februari 1925, hlm. 31.

74 British North Borneo Herald, "Stevenson Scheme Benefits", 2 Februari 1925, hlm. 21.

75 British North Borneo Herald, "Defence of Stevenson Scheme", 16 Februari 1925, hlm. 32.

76 McFadyean, Andrew, The History of Rubber Regulation 1934-43, London: G. Allen \& Unwin for the International Rubber Regulation Comitee, 1944, hlm. 80 .

77 British North Bomeo Herald, "Stevenson Scheme Benefits", 2 Februari 1925, hlm. 21.

78 British North Borneo Herald, "For Stability in Rubber", 2 Mac 1925, hlm. 38.

79. Jika Skim Stevenson terus beroperasi, negara-negara peserta akan mengalami lebih banyak kerugian dan jurang perbezaan diantara mereka dengan pengusaha di negara-negara yang tidak menyertai skim akan bertambah. Oleh itu, apabila negara bukan peserta menikmati faedah daripada pelaksanaan skim ini, maka adalah lebih baik jika ia ditamatkan sahaja. Pengumuman penamatan skim ini dilakukan oleh Perdana Menteri Britain pada bulan April 1928. Lihat Kuat Kwai Fong, Perkembangan Ekonomi Ladang Di Sabah 1881-1941, hlm 299.

$80 \quad$ Ibid., hlm. 299. 
81 S/F 1456C, Surat Makluman Setiausaha Kerajaan, Frank G. Smith kepada Pengarah Urusan Syarikat Berpiagam Borneo Utara (SBBU) yang beralamat di 17, St Helen's Place E.C.3, bertarikh 11 April 1930.

82 Pemimpin Cina dan tempatan yang terlibat sebagai pekebun kecil di Tenom telah menemui Pegawai Daerah dan menyatakan persetujuan mereka terhadap skim yang dirancang.

83 S/F 1456C, (R.O.I. Contiden 3/30), Surat sulit, Pemangku Residen Bahagian Pedalaman kepada pihak kerajaan di Sandakan, Pejabat Residen Pedalaman, Keningau, 16 April 1930.

84 S/F 1457C, (G.S.O. No. 572/30, Sheet No. 265), Surat Pemangku Setiausaha kepada Gabenor Borneo Utara, Mr.A.F. Richards, bertajuk Kawalan Pengeluaran Getah (Ristriction of Rubber Output), 17 April 1930.

85 S/F 1456C, (R.O.S 129/30), Surat Pemangku Residen kepada Setiausaha Kerajaan di Sandakan, Pejabat Residen, Sandakan, 28 April 1930.

86 S/F 1456C (R.7. 115/30) Surat Residen Tawau kepada Setiausaha Kerajaan di Sandakan, Pejabat Residen Tawau, 1st Mei 1930.

87 S/F 194 (G.S.O. No. 572/30 Sheet No. 4) Kertas Minit Setiausaha Kerajaan, 30 April 1930.

88 K.G. Tregonning, A History of Modern Sabah: North Borneo, 1881-1963, Singapore: University of Malaya Press, 1965, hlm. 90.

89 S/F 1455C (G.S.O. No. 00151) Memorandum Sulit bertajuk "North Borneo Claim for Additional Rubber Quota Recopitulated and Reconsider in the Light of the Decisions Taken on the $20^{\text {th }}$ November by the International Rubber Regulation Committee", hlm. 2.

90 Ibid., hlm. 3.

91 Ibid., hlm. 4.

92 Ibid., hlm. 6.

93 Ibid., hlm. 7.

$94 \quad$ Ibid., hlm. 6.

95 Ibid., hlm. 7.

96 British North Borneo Herald, 16 September 1938, hlm. 177.

97 Kuat Kwai Fong, Perkembangan Ekonomi Ladang Di Sabah 1881-1941, hlm. 326. 